too difficult for the average man. 2. Selection of an easy living language. This also has the experience of centuries against it. No living language is easy enough. No living language can surmount the barrier of international jealousy. 3. Invention of an easy and neutral language. This has been attempted some hundreds of times. Naturally, all these artificial languages have been neutral enough, but so far only one has been easy enough. And this anique language is Esperanto.

Its easiness. - That Esperanto is easy anyone may prove to himself at the cost of a few pence and a few minutes. Its inventor says, "My whole grammar can be learned perfectly in one hour." Leo Tolstoy says that in two hours he was able to read Esperanto fluently. Sir William Ramsay says that an English child in six months can read, speak, and write it. My own experience is confirmatory so far as reading is concerned, but, of course, accurate writing is more difficult and fluent speaking is more difficult still. Yet by dint of teaching a class I have satisfied myself that illiterate Englishmen can acquire the language in an astonishingly short time.

The simplicity of Esperanto depends on the following facts : 1. All international words are transferred to Esperanto with merely a phonetic modification-e.g., teatro, telefono. This practice is an especial boon to the reader of medical literature, for in such writings international words bulk largely. 2. There is a groundwork of easy root words (about 2000 ), most of which are known already to an educated man. 3 . These are varied by the addition of about 36 affixes, whereby extraordinary precision and most copious diction are attainable. 4. Grammatical inflections are cut down to the minimum, and, being based on the vowels $a, e, i, o$, and $u$, they are easily remembered as well as euphonic. 5. Pronunciation is unmistakeable. It is rigidly phonetic. Each letter is sounded. The word-stress is always on the secondlast syllable.

Its adequacy. - That Esperanto is adequate for converse between doctor and patient follows from the fact that it is adequate for all the ordinary relations of life. Recently on being introduced to a young German who knew no English, I found that we were mutually comprehensible in Esperanto. Here is another testimony : "Yesterday a young man comes to my house and asks to speak with me. I meet him, and he greets me forthwith in Esperanto. It is a young Russian. He knows not a word of French, I cannot speak a syllable of Russian. But we had our dear lingvo internacia in which we conversed for a good hour without even noticing any difference in our mode of pronunciation. And yet we had learned it by ourselves, from a little text-book, thousands of miles from one another." (M. d'Eyssautier.) Here is yet another witness : "I can prove to our sceptical friends that, without knowing a single foreign language, I am corresponding with persons of 17 different nationalities, amongst whom are to be found Frenchmen, Germans, Englishmen, Swedes, Norwegians, Italians, Spaniards, Portuguese, Americans, Africans, \&c." (Dr. J. Ostrovski.) Moreover, those who have taken part in the various international Esperanto congresses aver that they have had no difficulty in conversing on all imaginable subjects with Esperantists of most diverse nationality. That Esperanto is adequate for use in international medical congresses follows also from its success in the various Esperantist congresses. At Dover in 1904 five nations took part ; at Boulogne in 190522 nations took part; and at Geneva in 190623 nations took part. Speeches, debates, and business, as well as concerts and plays and social gatherings are all easily practicable in Esperanto.

That Esperanto is adequate for the purposes of medical literature can be learned from the study of one number of the Internacia Revuo Medicina. ${ }^{1}$ Thanks to the number of international words in medical writings any practitioner ought to be able to read this Revuo with no better aid than a halfpenny key to Esperanto. Then he will see that Esperanto can express all that English or French can convey and the parallel columns will prove to him that it is more terse than either. Indeed, considering that the inventor of Esperanto, Dr. Ludovic Zamenhof, is a practising medical man, it is only to be expected that the language should be suitable for meäical purposes. Growing numbers of practitioners have been learning it in Britain and far greater numbers have mastered it abroad. An Esperanto medical dictionary is in preparation.
Suggestions.-I have tried to show that Esperanto may prove useful in the course of medical practice, that Esperanto must prove useful at international medical congresses, and that Esperanto has proved useful in the publication of international medical literature. I would suggest, in conclusion : 1 . That Esperanto should be made a compulsory subject in our medical preliminary examinations, and that in all medical schools the students should be encouraged to read, and write, and speak in Esperanto. This, with their native tongue, will suffice them for scientific purposes all the world over and will save them their laborious yet unfruitful study of the other modern languages. 2. That Esperanto should be adopted as an official language at international medical congresses. It will speedily oust its rivals. 3. That, as a preparatory measure, each nation should appoint a standing medical literature committee, which would annually decide what among the records published in its mother tongue are of permanent value, and would forward that material to an international committee for republication in Esperanto.

As a hobby. - But it would be unfair to close without a word or two on the attractiveness of the study of Esperanto as a hobby for medical men. It is a quiet and clean occupation; it can be pursued in the pauses of one's practice; it is in itself a keen intellectual pleasure ; it opens up a wide and curiously varied range of literature; it throws a marvellous light on our English language, on grammar, and on points of style. Withal, proficiency in this language is rapidly attainable; every one may reasonably count on mastery ; and then there comes the strong delight of wielding skilfully this brilliant, supple, clear, and comely mental tool. Further, Esperanto broadens a man's outlook ; it can give to the loneliest country doctor correspondents and human interests in every quarter of the globe; it can make him indeed a citizen of the world and a universal brother. More than that, it has realised to such an extent the vague, expectant aspirations of our time that for many a man and woman, even now, it shadows forth the coming world religion.

July 20th, 1907.

$$
\text { I am, Sirs, yours faithfully, }
$$

W. Winslow Hall, M.D. Edin. Diplomito de la Brita Esperantista Asocio.

\section{BEES' STINGS AND RHEUMATISM.}

\section{To the Editors of THE LANCET.}

SIRs,- In connexion with the correspondence which has appeared in your columns upon the subject of bees' stings and rheumatism, it is interesting to recall that several years ago a patient wrote me asking whether physicians of to.day continued to use bees for stinging the inflamed joints in rheumatism as a curative measure, stating that he had read in an ancient classic, the reference to which $I$ have forgotten, that such treatment was practised along the eastern shores of the Adriatic, I believe, at some time prior to the Christian era. I am, Sirs, yours faithfully,

Chicago, June 17th, 1907. EDWARD F. WELLS, M.D.

\section{THE SHADOWGRAPH BOUGIE IN URETERIC SURGERY.}

To the Editors of $\mathrm{THE} \mathrm{LANCET}$.

SIRs,-Few surgeons, I take it, who are working at renal or ureteric surgery would care to operate withont the advantage of a good shadowgraph ureteric bougie. In a small number of cases the bougie is indispensable, for it enables the surgeon to detect false radiographic shadows and thus to avoid an extensive exploration upon the pelvic part of the ureter.

Unfortunately, a foreign firm has placed upon the market a shadowgraph ureteric bougie which exactly resembles the bougie used in England, the Marshall shadowgraph bougie. A foreign specimen was handed to me and to prove its value I placed it and a Marshall bougie on a radiographic plate. The foreign-made bougie left a faint shadow but the Marshall a strong black shadow. To obtain the best results it is necessary to secure the Marshall or one which casts an equally strong shadow.

I am, Sirs, yours faithfully,
Savile-row, W., July 22nd, 1907.
E. HuRry F ENwick. 